\title{
Indian Giant Squirrel (Ratufa indica) Distribution pattern, Habitat Structure and Characteristics in the Grizzled Giant Squirrel Wildlife Sanctuary, Srivilliputhur, Tamil Nadu, India
}

\section{Naresh Baja* ${ }^{\text {* }}$ Ambalavanan Sankari', Nagarajan Baskaran', Rajarathinavelu Nagarajan', Murali Saravanan²}

${ }^{1}$ P.G. and Research Department of Zoology and Wildlife Biology, A.V.C. College (Autonomous), Tamil Nadu. India

${ }^{2}$ Asian Nature Conservation Foundation, Indian Institute of Science, Bangalore, India

Study Area: Srivilliputhur, Tamil Nadu, India Coordinates: $9^{\circ} 21^{\prime}$ to $9^{\circ} 48^{\prime} \mathrm{N}$ and $77^{\circ} 21^{\prime}$ to $77^{\circ} 46^{\prime} \mathrm{E}$

Key words: Tree density, Habitat assessment, Relative abundance, Western Ghats

\section{Abstract}

An attempt has been made to study the distribution pattern and habitat characteristics of the Indian Giant Squirrel (Ratufa indica) at Grizzled Giant Squirrel Wildlife Sanctuary, which is a part of the Periyar-Agasthyamalai landscape of Southern Western Ghats, Tamil Nadu, Southern India. The study results revealed that the R.indica is widely distributed in moist deciduous forest followed by evergreen forest and not located in dry thorn forest habitat. Among the 17 habitat variables studied, 14 variables were signif icantly higher in $R$. indica distribution area than those in the non-distribution area. Tree species density and GBH were significantly higher in R.indica distribution area (density: $442 \pm 13.12, \mathrm{GBH}=81 \pm 1.56$ ) than that of nondistribution area (density: $318 \pm 6.3, \mathrm{GBH}: 57 \pm 0.68$ ) (density: $\mathrm{t}$-test, $\mathrm{df}=153, \mathrm{P}<0.05$ and GBH: $\mathrm{t}=-7.27, \mathrm{df}=169, \mathrm{p}<0.05)$. The present distribution pattern and habitat characteristics of $R$. indica in the area provides baseline data for future studies. The study is also addressed the issue of an urgent need of survey the status, distribution, abundance and habitat utilization patterns of R.indica in the studied area.

landscape dynamics have received less attention (Linderman et al., 2006).

The distribution of the R.indica has been reduced to isolated forest patches due to the forestry operations and tree felling (Borges et al., 1992). Therefore, data on distribution and the influence of tree species (composition, density, diversity and their characteristics) on the habitat selection by R.indica are out most important for long-term conservation plans. Though the species is known to exist widely in Southern India, very few studies (Datta, \& Goyal, 1996; Baskaran et al., 2011) have documented the influence of the tree species on the occurrence R.indica in different habitats. The present study was carried out to provide baseline information on population distribution and its influence on tree species and their characteristics for the long-term sustainability of the species in the study area.

\section{Materials and methods:}

Study area: the Grizzled Giant Squirrel Wildlife Sanctuary is a part of the Periyar-Agasthyamalai landscapes are increasingly well recognised. However, the combined effects of natural and human disturbances on

*Corresponding Author: nareshwildlife@gmail.com 
landscape (Fig. 1), one among the four landscapes of the Western Ghats. The area declared as a Wildlife sanctuary in 1989 and it extended over $480 \mathrm{~km}^{2}$. The altitude varies widely from $200 \mathrm{~m}$ in the plains to $2019 \mathrm{~m}$ (Kottaimalai). It receives a mean annual rainfall of $849 \mathrm{~mm}$ but varies from 700 to $3000 \mathrm{~mm}$, from both southwest and north-east monsoons with major share from the latter one. Madurai Forest Division is bordering its northern side, the Theni Forest Division and Periyar Tiger Reserve are on the western side and Thirunalveli Forest Division is on the southern side. It consists of four ranges namely Rajapalayam, Srivilliputhur, Watrapand Saptur (Fig. 1).

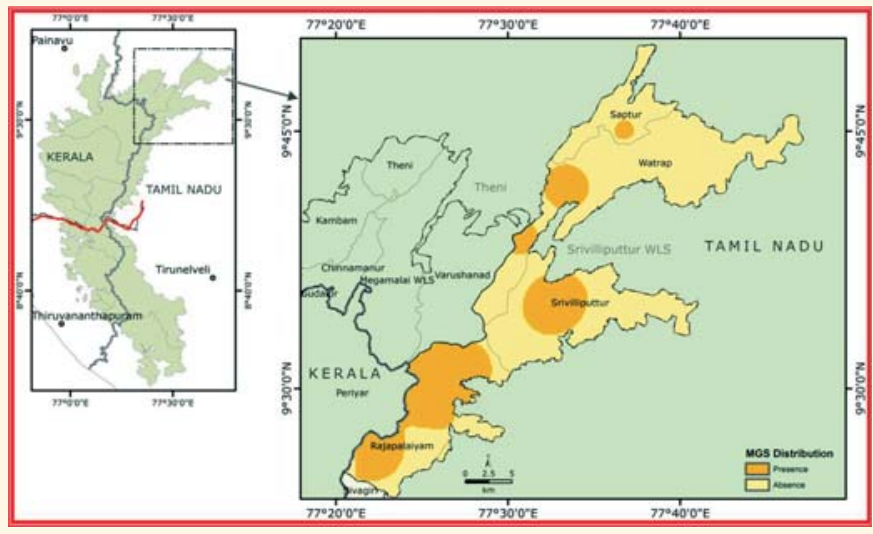

Figure-1: The distribution of R.indica in the studied area

Distribution Pattern: it was studied by following line transect method (Burnham et al., 1980). The line transect sampling location was identified through systematic random sampling: i.e. by overlaying a $4 \mathrm{~km}^{2}$ grid on 1:50,00o topographic maps of the sanctuary. All the grids were numbered resulting in an overall of 128 grids. The sampling was carried out in alternative grids at 64 grids. In total, the 64 transects (each varying from 1-2 km length), covering $121 \mathrm{~km}$ total length was laid systematically covering all the habitats and microhabitats across the sanctuary. Transects were walked during morning (o6:0o-10:oo h) or evening (16:00-18:0o h).

Habitat assessment (Quadrat Method): as the Indian Giant Squirrel is a canopy dwelling species, the tree species composition and tree characteristics were known to influence its distribution (Baskaran et al., 2011). To assess the tree species composition, density, and diversity, a quadrat $(20 \times 20 \mathrm{~m})$ was laid using $20 \mathrm{~m}$ tape at every $250 \mathrm{~m}$ interval of the line transect (Fig. 2). In total 484 such quadrats were laid. In these quadrats, all the tree species $>20 \mathrm{~cm}, \mathrm{GBH}$, canopy cover percentage, cattle grazing and the human disturbance sign on the quadrat were recorded. In addition, we collected tree species characteristics for four individuals from each quadrate, sampling trees were selected by selecting the one individual at each corner of the quadrate (Fig. 2). In total 1915 trees were sampled and recorded the following variables: (i) Tree height $(\mathrm{m})$ (ocular measurements), (ii) Tree GBH $(\mathrm{cm})$ measured using a tape measure, (iii) Total number of branches, (iv) Canopy contiguity to neighbouring trees on four major directions, as well as up to $10 \mathrm{~m}$ distance (by rating method: presence rated as $25 \%$ / direction or absence: rated as o\%), (v) Canopy height $(\mathrm{m})$ (ocular measurements), (vi) Canopy length (m) (ocular measurements) (vii) Canopy width $(\mathrm{m})$ : (in meter by ocular measurements) (viii) canopy shape (circular, oval and irregular).

$2 \mathrm{~km}$

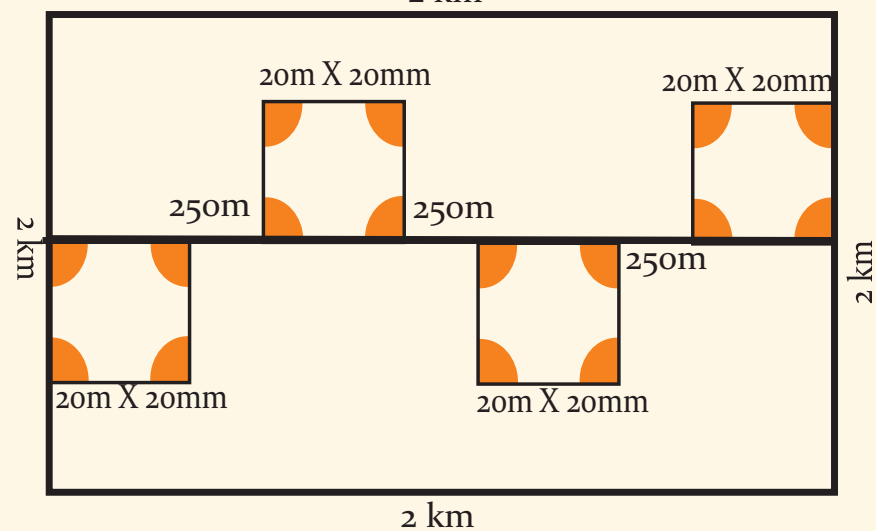

Figure-2: Diagrammatic representation of quadrate established for habitat assessment sampling along the line transect within the sampling grid.

Data Analysis: distribution areas are those where population estimate yielded either direct or indirect evidence (nest) or both. Non-distribution areas those where population estimate yielded neither direct nor indirect evidence (nest). Computing the number of species and their total individuals from each quadrat, estimated the individual and overall tree species density, tree species diversity (Shannon-Weiner index) separately for the $R$. indica presence and absence areas. Similarly, tree species characters were computed to arrive at the mean value of each parameter in distribution and nondistribution areas. The observed difference in all the parameters studied between distribution and nondistribution areas was tested for statistical significance using Two-sample "t" Test. In addition, binary logistic regression was performed taking into account all the variables (tree density, diversity, richness, \% canopy cover and other tree species characters) assessed between R.indica distribution and non-distribution areas.

\section{Results and Discussion:}

Distribution and relative abundance of Indian Giant Squirrel in the study area: data on a direct sighting of giant squirrel and its nesting location collected across all the major habitats in four ranges showed its distribution to be discontinuous or patchy in the sanctuary. The species is distributed contiguously, relatively over a larger area in the southern side (Rajapallayam Range) as compared to the northern side of the sanctuary (Watrap and Saptur Ranges) (Fig. 1). Relative abundance estimated using 
RESEARCH ARTICLE

encounter rate of direct sightings and nest $/ \mathrm{km}$ walk in different habitat showed that moist deciduous forest had the highest abundance followed by evergreen and dry deciduous forest (Fig. 3). The species or its nest was not encountered in dry thorn and high altitude grassland habitats. Similarly, abundance estimated in four forest ranges: Rajapalayam (0.7/ km), Srivilliputhur (0.2/ km) and Watrap (o.1) while the lowest encounter rate (0.02/ km) was recorded in Saptur range (Fig. 4).

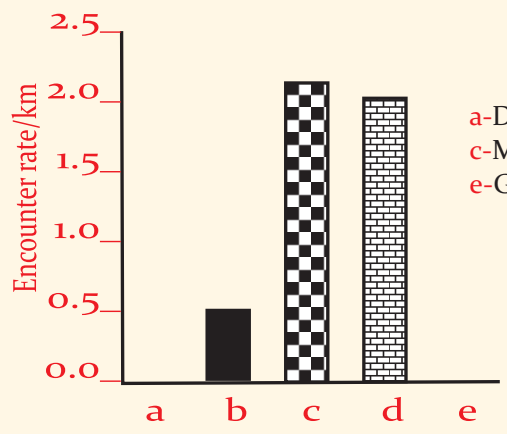

a-Dry thorn; b-Dry deciduous; c-Moist deciduous; d-Evergreen; e-Grassland

Figure-3: Abundance of R.indica recorded in different habitat types

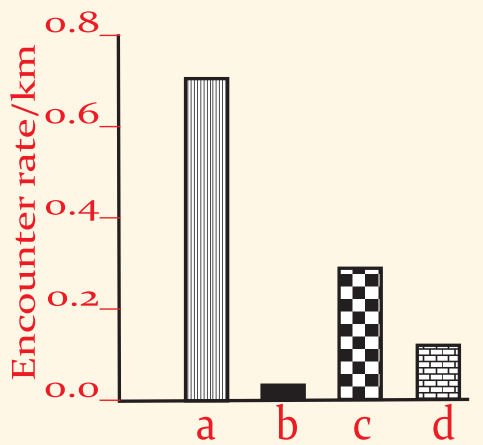

Forest Ranges

a-Rajapallayam;

b-Satpur

c-Seivilliputhur;

d-Watrap

Figure-4: Abundance of $R$. indica recorded in different forest ranges

Table-1: Tree species density, diversity and characters in Indian Giant Squirrels distribution and non-distribution areas

\begin{tabular}{|c|c|c|c|c|c|c|}
\hline . & Para & $\begin{array}{l}\text { Distrib } \\
\text { area }\end{array}$ & $\begin{array}{l}\text { Nondistri- } \\
\text { bution area }\end{array}$ & 't' & 'p' & $\overline{\mathrm{DF}}$ \\
\hline & Tree density /ha & $442 \pm 13.12$ & $318 \pm$ & -8.51 & o & 153 \\
\hline 2 & Tree GBH / tree & $81 \pm 1.56$ & $57 \pm 0.68$ & -7.27 & o & 169 \\
\hline 3 & Diverity Shannon/pl. & $3.26 \pm$ & $3.88 \pm$ & 25.12 & o & 173 \\
\hline 4 & Species Richness/pl. & $17 \cdot 70 \pm 5.36$ & $12.74 \pm 4.91$ & -8.51 & o & 153 \\
\hline 5 & Canopy cover \% & $67 \pm 0$ & $38 \pm$ & -11.1 & o & 146 \\
\hline 6 & $\begin{array}{l}\text { Cano } \\
\text { by he }\end{array}$ & 41 & 76. & 10.06 & o & 374 \\
\hline 7 & $\begin{array}{l}\text { Main } \\
\text { by hy }\end{array}$ & 8 & 1 & 0.39 & o & 151 \\
\hline 8 & Tree height $(\mathrm{m}) / \mathrm{t}_{1}$ & 16. & & -9.91 & o & 133 \\
\hline 9 & Tot & 48 & & -7.06 & o & 124 \\
\hline 10 & Can & $10.05=$ & 7.12 & $-7 \cdot 73$ & o & 145 \\
\hline 11 & lt. $(\mathrm{m}) /$ tree & $10.03 \pm 0.22$ & 7.13 & -7.63 & o & 147 \\
\hline 12 & width $(\mathrm{m})$ & $7.6 \pm 0.16$ & 08 & -7.04 & o & 173 \\
\hline 13 & $\begin{array}{l}\text { Canc } \\
\text { circu }\end{array}$ & 8.4 & 10.05 & 0.96 & 0.34 & 173 \\
\hline 14 & $\begin{array}{l}\text { Cano } \\
\text { irreg }\end{array}$ & 80.3 & 74 . & -2.72 & 0.007 & 175 \\
\hline 15 & Can & 15 & & 2.76 & 0.006 & 205 \\
\hline 16 & $\begin{array}{l}\text { Canopy continuity\% } \\
\text { in } 4 \text { directions }\end{array}$ & $58.57 \pm 1.69$ & $48.45 \pm 0.71$ & -3.19 & 0.002 & 137 \\
\hline 17 & $\begin{array}{l}\text { Canopy continuity } \\
10 \mathrm{~m}(\%) \text { in four dire }\end{array}$ & $85.5 \pm 1.37$ & $58.21 \pm 0.98$ & -9.23 & o & 217 \\
\hline
\end{tabular}

Ambient Science (2017)

http://www.caves.res.in/
Ambient Science, 2017: Vol. 04(1); 57-61 DOI:10.21276/ambi.2017.04.1.ra01

Tree species composition and characteristics in the study area: tree species composition and characters assessed in R.indica distribution and non-distribution areas of the Sanctuary are given in Table 1. Among the 17 variables studied, 14 variables were signif icantly higher in distribution area than those in a non-distribution area. Tree species density and GBH were signif icantly higher in R.indica distribution area (density: 442 $\pm 13.12, \mathrm{GBH}=$ $81 \pm 1.56)$ than that of non-distribution area (density: 318 \pm 6.3 , GBH: 57 \pm 0.68 ) (density: $\mathrm{t}-$ test, $\mathrm{df}=153, \mathrm{p}<0.05$ and GBH: $\mathrm{t}=-7.27, \mathrm{df}=169, \mathrm{p}<0.05)$. Though the diversity of trees was lower in animal distribution area $(3.2617 \pm 0.02161)$ than the non-distribution area $(3.8843 \pm$ o.0121), distribution area had significantly higher species richness $(17.70 \pm 5.36)$ and canopy cover $(67 \pm 0.57)$. Tree height $(\mathrm{m})$, a number of branches, canopy height $(\mathrm{m})$, canopy length $(\mathrm{m})$ and canopy width(m) were also significantly higher in the distribution area than that of the non-distribution area (Table-1). There was no signif icant difference in canopy shape circular ( $\mathrm{t}$-test, $\mathrm{df}=$ 173, p > 0.05). Canopy breaking and main stem cutting by the human were significantly higher in non-distribution areas (Table-1). These results indicate that human activity has negative influence on the distribution of R.indica and therefore they are avoiding certain places in the sanctuary.

Further, Binary logistic regression was used taking the R.indica distribution dependent variable and tree species attributes (density, diversity, richness), tree characters (canopy cover, tree height, number of branches, canopy, height, length, and width, canopy shape and its contiguity in four major directions as well as up to 1om and human disturbances: (lopping and main stem cut) to understand the collective effect of each variable on the distribution of R.indica (Table-2). The analysis showed five (tree species diversity, main stem cut by human, mean number of branches, canopy width mean, canopy cover $\%$ up to $10 \mathrm{~m}$ in four major directions) out of 17 variables tested had either positive (i.e. number of branches, canopy cover up to $10 \mathrm{~m}$ distance) or negative relationship (tree diversity, main stem cut by human and canopy width) with the distribution of R.indica. The remaining 12 variables (density, richness, canopy cover (\%) and contiguity, tree height, canopy height, and length, canopy shape: circular, oval and irregular, and lopping by human ) turned out insignificant indicating no impact of these variables on the distribution of the R.indica. These results indicate the importance of maintaining canopy contiguity and decreasing the human disturbances in R.indica habitats to retain the species in its natural habitats. The results of the present study show that the R.indica distribution is discontinuous in the study area. The reason for such patchy distribution could be due to tree species composition or discontinuous canopy contiguity. Data on squirrel abundance in different habitat from the present 
Table 2. Binary logistic regression tested for tree species attributes and characteristics in distribution and non-distribution area of $R$. indica

\begin{tabular}{llllllll}
\hline Predictor & Coefficient & SE & Z & P & Odds Ratio & $\begin{array}{c}\text { 95\% Confidence limit } \\
\text { Lower }\end{array}$ \\
& & & & & & \\
Upper
\end{tabular}

study show that R.indica abundance was higher in the moist deciduous and evergreen forests, lower in dry deciduous and completely absent in dry thorn and grass land habitats. Among the five habitats, canopy contiguity is expected to be higher in habitat with high rainfall i.e. evergreen and moist forests than in dry deciduous and dry thorn forests and could be very scanty or virtually nil in the grassland due to very low density or absence of tree cover in this habitat. The observed abundance results of R.indica in different habitats go in support of the above statements that canopy cover positively influences the distribution of $R$.indica. Some studies reported an absence or patchy distribution of $R$.indica only along the riverine habitats in dry thorn forests due to poor canopy contiguity (Desai et al., 1999; Baskaran et al., 2011). These studies (Desai et al., 1999; Baskaran et al., 2011) have also pointed the effect of selection felling of mature trees prevailed in the past on the distribution of R.indica and highlighted the need for maintaining the canopy contiguity. Further, the abundance data in relation to forest ranges i.e. highest in the Rajapalayam Range followed by Srivilliputhur and lowest in northern side forest ranges like Watrap and Saptur could be a function of canopy contiguity and tree species composition. As shown in vegetation and land use map (Fig. 5), the majority of areas on the northern side of the sanctuary (Watrap and Saptur Ranges) are occupied by dry thorn forests and high altitude grassland habitats, which is known to have poor canopy contiguity. Therefore, $R$.indica patchy distribution and absence in dry thorn and grass land habitats as well as on the northern parts of the sanctuary could be a function of canopy contiguity and tree species composition as reported elsewhere (Borges, 1989; Datta \& Goyal, 1996; Baskaran et al., 2011; Ramachandran, 1992; Rout \& Swain, 2005).

The present study compared tree species attributes and their character: 17 different variables with the distribution pattern of $R$. indica (presence/absence area). Of which, tree species density, GBH, richness, canopy cover, tree height $(\mathrm{m})$, the number of branches, canopy height $(\mathrm{m})$, canopy length $(\mathrm{m})$ and canopy width were signif icantly higher in $R$. indica distribution area than that of the non-distribution area. While on the other hand canopy breaking and main stem cutting by a human were significantly higher in non-distribution areas indicating

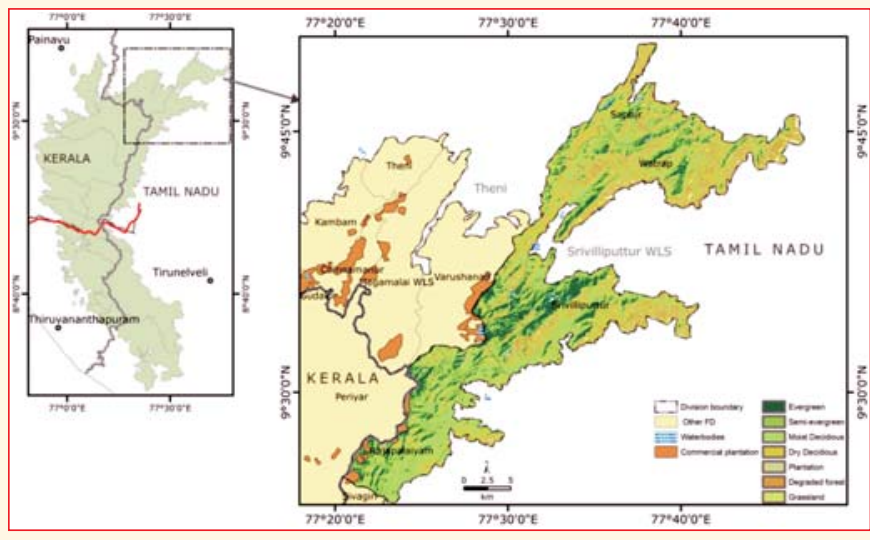

Figure 5. Land use and vegetation map of the Grizzled Giant Squirrel Wildlife Sanctuary

that positive effect of tree density, diversity, richness and their characteristics and the negative effect of human disturbances on the distribution of R.indica. R.indica, being a canopy-dwelling species, occasionally comes to the ground (Ramachandran, 1988), mostly to overcome breaks in canopy continuity. Further, the species mostly feeds on seeds, leaves, flowers and bark from trees and constructs globular nests or dreys with leaves and twigs (Thorington \& Cifelli, 1989; Ramachandran, 1992). Considering its arboreal nature and dependence on trees for food, shelter, and movement, it is apparent that the composition of tree species and structural attributes of the forests play a major role in the use of the habitat by the giant squirrel (Ramachandran, 1992; Borges, 1989; Datta \& Goyal, 1996). The Binary logistic regression showed that positive correlation of R.indica distribution with a number of branches, canopy cover and negative correlation with tree diversity, main stem cut by human and canopy width further revealed the importance of maintaining canopy contiguity and decreasing the human disturbances in R.indica habitats to retain the species in its natural habitats.

\section{Acknowledgements:}

I sincerely thanks to Dr. K. Thiyagesan, Principal of A.V.C. College, Mannampandal who has extended all possible way for the successful completion of this project. I express my gratitude to Dr. M. Varadharajan, Head and all staff members of the Department of Zoology and Wildlife Biology, for their constant encouragement and permitting me to use the department field 


\section{RESEARCH ARTICLE}

instruments. I am extremely thankful to Dr. Shekhar Kumar Niraj I.F.S. Conservator of Forests, Viruthunagr Circle, and Mr. Ashok Kumar, I.F.S., Wildlife Warden, Srivilliputhur division, Tamilnadu forest department for granting permission to do my fieldwork at Grizzled Giant Squirrel WildlifeSanctuary.

\section{References:}

Baskaran, N., Venkatesan, S., Mani, J., Srivastava, S.K. \& Desai, A. (2011): Some aspects of the ecology of Indian Giant Squirrel (Ratufa indica Erxleben, 1777) in the tropical forests of Mudumalai Wildlife Sanctuary, southern India and their conservation implications. L. Thr. Taxa., 3(7):1899-19o8.

Borges, R.M., Mali, S. \& Ranganathan, S. (1992): The status, ecology and conservation of the Indian Giant Squirrel (Ratufa indica). Draft Technical Report No.1 (submitted to Wildlife Institute of India). Indo-US Project.

Borges, R. (1989): Resource heterogeneity and the foraging ecology of the Malabar Giant Squirrel (Ratufa indica). PhD Thesis, University of Miami, Florida.

Burnham, K.P., Anderson, D.R. \& Laake, L.L. (1980): Estimation of density from line transects sampling of biological population. Wildlife Monographs. 72 (1): 202.

Ceballos, G. \& Ehrlich, P.R. (2002): Mammal population losses and the extinction crisis. Science, 296: 904-907.

Datta, A. \& Goyal, S.P. (1996): Comparison of forest structure and use by the Indian Giant Squirrel (Ratufa indica) in two riverine forests of Central India. Biotropica, 28(3):394-399.

Desai, A.A., Baskaran, N., Venkatesan, S. \& Mani, J. (1999): Ecology of Malabar Giant Squirrel (Ratufa indica) in Mudumalai Wildlife Sanctuary and Natinal parks. Technical Report. Bombay Natural History society and Tamilnadu Forest Department.

Gurnell, J. (1987): The Natural History of Squirrels, (Natural History Series). Pub. by: Facts on File, New York.

Lemos de Sa, R.M. \& Strier, K.B. (1992): A preliminary comparison of forest structure and use by two isolated groups of woolly spider monkeys, brachyteles, arachnoides.Biotropica, 24:455-459.
Ambient Science, 2017: Vol. 04(1); 57-61 DOI:10.21276/ambi.2017.04.1.ra01

Linderman, M.A., An, L., Bearer, S., He, G., Ouyang, Z and Liu, J. (2006), Interactive effects of natural and human disturbances on vegetation dynamics across landscapes. Ecol. Appl., 16(2): 452-463.

Nandini, R. \& Parthasarathy, N. (2008): Food habits of the Indian giant flying squirrel (Petaurista philippensis) in a rain forest fragment, Western Ghats. J. Mamm., 89(6):1550-1556.

Ramachandran, K.K. (1992): Certain aspects of ecology and behaviour of Malabar Giant Squirrel Ratufa indica (Schreber). PhD Thesis. Department of Zoology, University of Kerala, 191 pp.

Ramachandran, K.K. (1988): Ecology and behaviour of Malabar Giant Squirrel Ratufa indica maxima (Schreber) 1788. Report of the Project Wild 04/83. Division of Wildlife Biology, Kerala Forest Research Institute, Peechi, Kerala, 47 pp.

Rout, S.D. \& Swain, D. (2005): Status of Giant Squirrel (Ratfa indica) in Similipal Tiger Reserve, Orissa, India. Ind. Forest., 131(10): 1363-1372.

Steele, M.A. \& Koprowski, J.L. (2001): North American Tree Squirrels, Smithsonian Institution. Pub. by: Smithsonian Books, Washington DC.

Smith, W.P., Gende, S. \& Nichols, J.V. (2005): The northern flying squirrel as an indicator species of temperate rain forest: Test of an hypothesis. Ecol. Appl., 15:689-700.

Thorington, R.W. \& Cifelli, R.L. (1989): The usual significance of the giant squirrels (Ratufa), pp. 212219. In: Daniel, J. C. and J. S. Serrao (eds.). Conservation in Developing Countries: Problem and Prospects. Proceeding of the Centenary Seminar of the Bombay Natural History Society. Oxford University Press.

Verbeylen, G., Wauters, L.A., De bruyn, L. \& Matthysen, E. (2009): Woodland Fragmentation affects space use of Eurasian red squirrels. Acta Oecol., 35: 94-103. 